\title{
Development of Ciona intestinalis Juveniles (Through 2nd Ascidian Stage)
}

\author{
Shota Chiba ${ }^{1 *}$, Akane Sasaki $^{1}$, Akie Nakayama ${ }^{1}$, \\ Katsumi Takamura ${ }^{2}$ and Nori Satoh ${ }^{1}$ \\ ${ }^{1}$ Department of Zoology, Graduate School of Science, Kyoto University, Sakyo-ku, \\ Kyoto 606-8502, Japan \\ ${ }^{2}$ Department of Marine Biotechnology, Faculty of Life Science and \\ Biotechnology, Fukuyama University, \\ Fukuyama 729-0292, Japan
}

\begin{abstract}
Following the reading of its draft genome sequence and the collection of a large quantity of cDNA information, Ciona intestinalis is now becoming a model organism for whole-genome analyses of the expression and function of developmentally relevant genes. Although most studies have focused on larval structures, the development of the adult form is also very interesting in relation to tissues and organs of vertebrate body. Here we conducted detailed observations of the development of tissues and organs in Ciona intestinalis larva and juveniles until so-called the 2nd ascidian stage. These observations included examination of the oral siphon, tentacle, oral pigments and atrial pigments, atrial siphon, ganglion and neural gland, longitudinal muscle, stigmata, transverse bar and languet, longitudinal bar and papilla, heart, digestive organ, gonad, endostyle, and stalk and villi. The findings from these observations make a new staging system for juvenile development possible. Based on the development of the internal organs, we propose here nine stages (stage $0 \sim$ stage 8 ) starting with swimming larvae and proceeding through juveniles until the 2 nd ascidian stage. These descriptions and staging system provide a basis for studying cellular and molecular mechanisms underlying the development of adult organs and tissues of this basal chordate.
\end{abstract}

Key words: Ciona intestinalis, juvenile development, staging

\section{INTRODUCTION}

Ciona intestinalis is one of the most cosmopolitan species of ascidians, and is used by researchers throughout the world (Satoh et al., 2003). Ciona intestinalis has a small genome (about $160 \mathrm{Mbp} / \mathrm{haploid}$ genome) containing approximately 15,500 genes (Simmen et al., 1998). The recent publication of the Ciona draft genome sequence revealed $\sim 117 \mathrm{Mbp}$ of euchromatic region with 15,852 protein-coding genes (Dehal et al., 2002). This genome size and gene number is comparable to those of Drosophila melanogaster. Ciona intestinalis can spawn year around with a generation time is about 2-3 months. These considerations make Ciona intestinalis one of the promising species for extensive genetic analyses (e.g., Sasakura et al., 2003).

Embryos of ascidians develop into swimming tadpole

\footnotetext{
* Corresponding author: Tel. +81-75-753-4082;

FAX. +81-75-705-1113.

E-mail: chiba@ascidian.zool.kyoto-u.ac.jp
}

larvae and then metamorphose into sessile adults. The larva has a notochord and dorsal nervous system, and this larval form represents a basic chordate body plan (Kowalevsky, 1866, 1871). However, larvae of most ascidian species do not have functional digestive organs. After the metamorphosis of most ascidians, tissues and organs used for the adult life differentiate. For example, the adult ascidian has digestive organs (pharynx, stigmata, endostyle, oesophagus, stomach, intestine and pyloric gland), a heart and a gonad, all of which are present only in the adult body. These organs are present in the vertebrate body too. Furthermore, the endostyle is thought to be homologous to the vertebrate thyroid gland (Barrington, 1964; Ogasawara et al., 1999). For these reasons, understanding the developmental mechanisms of Ciona adult tissues is as important as understanding those of larval tissues.

In recent years, our lab has been breeding Ciona intestinalis from eggs to adults. The expression profiles of Ciona juvenile genes have been well described by Ogasawara et al. (2002) and it is possible to analyze mechanisms of adult 
development with respect to many genes using genomic and EST databases (Satoh et al., 2003).

To date, many researchers have reported studies of the development of ascidian juveniles. For example, Willey (1893a, b) described the development of the protostigmata, heart, ganglion, neural gland, endostyle and gonad. In addition, Yamamoto and Okada (1999) described the development of the gonad at ultrastructural level, and Damas (1899) described heart development, while Sato described tail resorption and rotation of the body axis (Sato et al., 1997; Sato and Morisawa, 1999). The relationships among the stigmata, longitudinal muscle, atrial siphon and heart during juvenile development were described by Berrill (1947). In addition, Hirano and Nishida $(1997,2000)$ traced cell lineages after metamorphosis in Halocynthia roretzi. However, those reports were based on specimens which were cultivated under uncontrolled breeding conditions in which the temperature varied greatly among studies, and therefore it is difficult to precisely compare the results of these observations. Here we describe the developmental patterns of various adult organs and tissues during Ciona intestinalis juvenile development.

\section{MATERIALS AND METHODS}

Adult Ciona intestinalis were cultured in Maizuru Fisheries
Research Station of Kyoto University. Eggs and sperm were collected from several adults in order to avoid accidentally making observations of natural mutants. Eggs and sperm were obtained by dissection of gonoducts. After artificial insemination, the fertilized eggs were cultured at $20^{\circ} \mathrm{C}$. Under this condition, larvae hatched about $14 \mathrm{hr}$ after fertilization. After metamorphosis, juveniles were thinned out until about 20 juveniles remained per $9-\mathrm{cm}$ petri dish to synchronize the development. Then, a few dishes were floated in a 4- $L$ tank containing of 3-L Millipore filtered seawater. Juveniles were fed the diatom Chaetoceros gracilis every 2 days. The seawater was changed every 2 days. Ciona were observed with microscopes (Axioplan 2, Carl Zeiss and SZH10, Olympus).

\section{RESULTS AND DISCUSSION}

\section{The 2 nd ascidian stage}

Berrill (1947) observed Ciona intestinalis juvenile development, focusing his attention on the formation of several tissues. In his report, he separated juvenile development into two stages. The first stage was called the 1st ascidian stage, and includes stages from that in which there are 2 protostigmata on each side in the pharynx until the stage prior to which the two pre-atrial siphons fuse with each other. The second stage was called the 2nd ascidian stage, at which the juveniles have 6 rows of protostigmata in their pharynx and the two pre-atrial siphons are fused with each

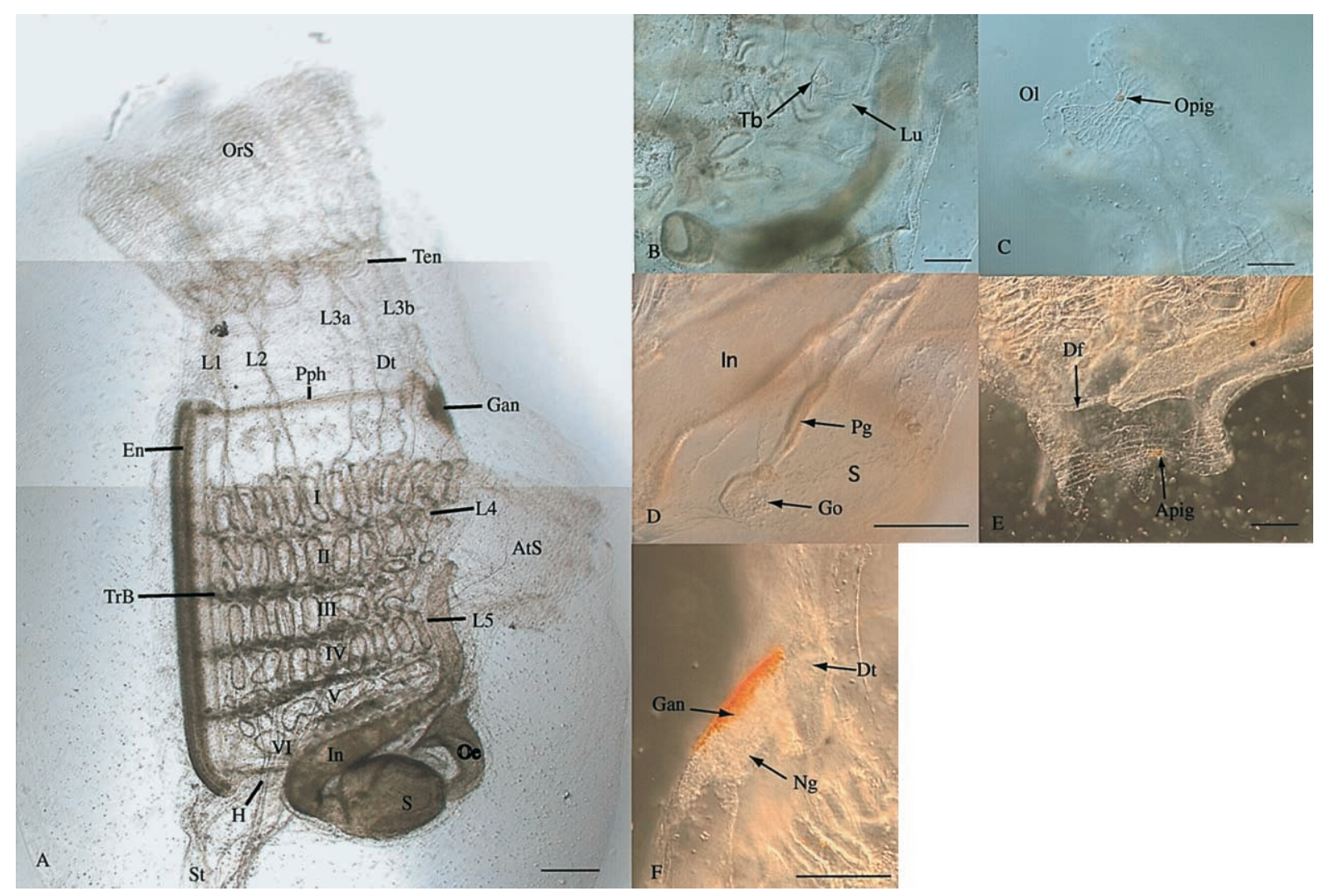

Fig. 1. The tissues and organs of the 2 nd ascidian stage of Ciona intestinalis. (A) The whole animal, (B) dorsal region, (C) the oral siphon, (D) around the gonad, $(E)$ the atrial siphon, and $(F)$ around the ganglion. OrS, oral siphon; Ten, tentacle; L1 to L5, longitudinal muscle L1 to L5; Pph, peripharyngeal band; Dt, dorsal tubercle; Gan, ganglion; En, endostyle; I to VI, protostigmata I to VI; TrB, transverse bars; AtS, atrial siphon; In, intestine; S, stomach; Oe, oesophagus; H, heart; St, stalk; Tb, tongue bud; Lu, lunguet; Ol, oral lobe; Opig, oral pigment; Go, gonad; $\mathrm{Pg}$, pyloric gland; Apig, atrial pigment; Df, dorsal fold; and $\mathrm{Ng}$, neural gland. Scale bars, $100 \mu \mathrm{m}$. 
other.

Willey (1893a) reported that "three pairs of gill-slits, in the guise of six primary stigmata, are represented in Ciona and other simple ascidians. In Ciona the innumerable branchial stigmata of the adult are derived by subdivision from these six primary stigmata, and not by new perforations". Roule (1884), Goodbody (1974), and Millar (1953) gave precise descriptions about each tissue of adult ascidians. As mentioned below, the organs and tissues of the 2nd ascidian stage are almost the same as those of the adult (Fig. 1).

\section{Oral siphon}

In the 2nd ascidian stage juveniles, the oral siphon is situated anterior to most of the body and has eight oral lobes with eight ocelli. The number of oral lobes is usually 8 but sometimes in nature we found animals that have 7 or 9 oral lobes. The transverse muscle is well developed around the oral siphon. The oral siphon is also called the mouth or branchial siphon (Table 1).

The oral siphon is observed in larvae 4-9 hr after hatching as the "oral siphon placode" (Fig. 2A). Then 12-24 hr

Table 1. The developmental stage of Ciona intestinalis juvenile

\begin{tabular}{|c|c|c|c|c|c|c|c|c|c|c|c|c|}
\hline \multirow[b]{5}{*}{ name } & \multirow[b]{5}{*}{ another name } & \multirow{2}{*}{\multicolumn{3}{|c|}{$\begin{array}{l}\text { SWIMMING LARVA } \\
\text { Swimming larva }\end{array}$}} & \multirow{2}{*}{\multicolumn{2}{|c|}{ Rotation of the body axis }} & \multicolumn{3}{|c|}{ JUVENILE } & & \multirow{3}{*}{$\begin{array}{l}\text { 2nd ascidian } \\
\text { day-12 14 }\end{array}$} & \multirow{3}{*}{$\begin{array}{l}\text { ADULT } \\
\text { Adult } \\
2.5-3 \text { months }\end{array}$} \\
\hline & & & & & & & & $1 \mathrm{st}$ & ascidian & & & \\
\hline & & \multirow{3}{*}{$\begin{array}{l}\text { 0-2 hr } \\
\text { Stage } 0 \\
\text { early- } \\
\text { swimming } \\
\text { larva }\end{array}$} & \multirow{3}{*}{$\begin{array}{l}\text { 2-4 hr } \\
\text { Stage } 1 \\
\text { mid- } \\
\text { g swimming } \\
\text { larva }\end{array}$} & \multirow{3}{*}{$\begin{array}{l}\quad 4-9 \mathrm{hr} \\
\quad \text { Stage } 2 \\
\text { late- } \\
\text { swimming } \\
\text { larva }\end{array}$} & \multirow{2}{*}{$\begin{array}{l}12-24 \mathrm{hr} \\
\text { Stage } 3 a\end{array}$} & \multirow{2}{*}{$\begin{array}{l}24-48 \mathrm{hr} \\
\text { Stage } 3 \mathrm{~b}\end{array}$} & \multirow{2}{*}{$\begin{array}{c}\text { day-3 } \\
\text { Stage } 4\end{array}$} & \multirow{2}{*}{$\begin{array}{l}\text { day-5 } \\
\text { Stage } 5\end{array}$} & \multirow{2}{*}{$\begin{array}{l}\text { day-7 8 } \\
\text { Stage } 6\end{array}$} & \multirow{3}{*}{$\begin{array}{c}\text { day-10 12 } \\
\text { Stage } 7 \\
\text { VI ptorostigmata }\end{array}$} & & \\
\hline & & & & & & & & & & & Stage 8 & Adult \\
\hline & & & & & early rotation & late rotation & $\begin{array}{l}\text { I, IV } \\
\text { protostigmata }\end{array}$ & $\begin{array}{l}\text { II, III } \\
\text { protostigmata }\end{array}$ & $\checkmark$ protostigmata & & 2nd ascidian & adult \\
\hline oral siphon & $\begin{array}{l}\text { mouth, } \\
\text { branchial siphon }\end{array}$ & & & oral placode & invagination & not contract & $\begin{array}{c}\text { contract } \\
6-8 \text { oral lobe }\end{array}$ & $6-8$ oral lobe & 8 oral lobe & 8 oral lobe & 8 oral lobe & $7-9$ oral lobe \\
\hline tentacle & $\begin{array}{l}\text { branchial tentacle, } \\
\text { oral tentacle }\end{array}$ & & & & & & 1st (6) & & 1st (8) 2nd(8) & & 1st (8), 2nd (8) & $1 \mathrm{st}-4$ th \\
\hline oral pigments & ocellus & & & & & & & $2-8$ can observed & pigmented & & 8 oral pigments & $7-9$ oral pigments \\
\hline atrial pigments & ocellus & & & & & & & & & & 6 atrial pigments & 6 atrial pigments \\
\hline atrial siphon & $\begin{array}{l}\text { atrial pore, } \\
\text { peribranchial siphon }\end{array}$ & & & $\begin{array}{l}\text { atrial } \\
\text { placode }\end{array}$ & invagination & not contract & $\begin{array}{l}\text { pre-atrial siphon } \\
\text { contract }\end{array}$ & & & began to fuse & an atrial siphon & an atrial siphon \\
\hline ganglion & brain & & & & & & & & & & clear & white \\
\hline neural gland & hypophysis & & & & & III (Willey) & & IV (Willey) & & & clear & white \\
\hline dorsal fold & dorsal strand & & & & & can observe & & & & & & \\
\hline dorsal tubercle & ciliated funnel & & & & & & & horse-shaped & & & & \\
\hline $\begin{array}{l}\text { longitudinal } \\
\text { muscle }\end{array}$ & & & & & & $L 1$ and $L 2$ & $L 1$ and L2 & $\begin{array}{l}\text { L1, L2, L3a, } \\
\text { L3b, L4 }\end{array}$ & $\begin{array}{l}\text { L1, L2, L3a, } \\
\text { L3b, L4 }\end{array}$ & $\begin{array}{l}\text { L1, L2, L3a, } \\
\text { L3b, L4, L5 }\end{array}$ & $\begin{array}{l}\text { L1, L2, L3a, } \\
\text { L3b, L4, L5 }\end{array}$ & $\begin{array}{l}\text { L1, L2, L3a, } \\
\text { L3b, L4, L5 }\end{array}$ \\
\hline $\begin{array}{l}\text { protostigmata } \\
\text { (stigmata) }\end{array}$ & gill, gill slit & & & & & $\begin{array}{l}\mathrm{I}(1), \mathrm{IV}(1) \text { but } \\
\text { not open }\end{array}$ & $\mathrm{I}(1), \mathrm{IV}(1)$ & $\begin{array}{l}\text { I(1), II(1), } \\
\text { III(1), IV(1) }\end{array}$ & $\begin{array}{l}\mathrm{I}(2), \mathrm{II}(1), \mathrm{II}(1) \\
\mathrm{IV}(2), \mathrm{V}(1)\end{array}$ & $\begin{array}{l}\mathrm{I}(4), \mathrm{II}(4), \mathrm{III}(4), \\
\mathrm{IV}(4), \mathrm{V}(2), \mathrm{VI}(1)\end{array}$ & $\begin{array}{l}\mathrm{I} \text { - IV (8-12), } \\
\mathrm{V}(4), \mathrm{VI}(4)\end{array}$ & many (stigmata) \\
\hline $\begin{array}{l}\text { pharyngeal } \\
\text { (pharynx) }\end{array}$ & branchial sac & & & & & can observe & & & & & & \\
\hline $\begin{array}{l}\text { transverse } \\
\text { bar }\end{array}$ & gill bar & & & & & & & $\begin{array}{l}\text { between II and } \\
\text { III protostigmata }\end{array}$ & $\begin{array}{l}\text { between I and II } \\
\text { and between III } \\
\text { and IV }\end{array}$ & $\begin{array}{l}\text { between IV } \\
\text { and V }\end{array}$ & $\begin{array}{l}\text { between } \mathrm{V} \text { and } \\
\mathrm{VI}\end{array}$ & $\begin{array}{l}\text { between each } \\
\text { rows of stigmata }\end{array}$ \\
\hline languet & & & & & & & $\begin{array}{l}\text { between I and IV } \\
\text { protostigmata }\end{array}$ & & $\begin{array}{l}\text { between I to II, III } \\
\text { and IV, and IV } \\
\text { and V }\end{array}$ & $\begin{array}{l}\text { between } \mathrm{V} \\
\text { and } \mathrm{VI}\end{array}$ & $\begin{array}{l}\text { each dorsal } \\
\text { end of } \\
\text { transverse bar }\end{array}$ & $\begin{array}{l}\text { each dorsal } \\
\text { end of } \\
\text { transverse bar }\end{array}$ \\
\hline longitudinal bar & & & & & & & & & one or two & & three or four & many \\
\hline papilla & & & & & & & tongue bud & elongation & $\begin{array}{l}\text { observed on } \\
\text { longitudinal bar }\end{array}$ & & & many \\
\hline heart & pericardium & & & & & & began to beat & & & round-shaped & round-shaped & $\begin{array}{l}\text { V-shaped with } \\
\text { pericardiac body }\end{array}$ \\
\hline blood cell & & & & & & & can observe & & & & & \\
\hline intestine & $\begin{array}{l}\text { mid-gut and } \\
\text { hind-gut, rectum }\end{array}$ & & & $\begin{array}{l}\text { intestine } \\
\text { disc }\end{array}$ & & $\begin{array}{l}\text { intestine (anus } \\
\text { opened at left } \\
\text { pre atrial siphon) }\end{array}$ & & & & & & \\
\hline oesophagus & esophagus & & & & & oesophagus & & & & & & \\
\hline stomach & & & & & & stomach & & & & & & \\
\hline pyloric gland & & & & & & & can observe & & & & & \\
\hline gonad & & & & & & $\begin{array}{l}\text { electron } \\
\text { microscopy } \\
\text { level }\end{array}$ & can observe & & oval vesicle & & oval vesicle & $\begin{array}{l}\text { ovary, oviduct, } \\
\text { testis, sperm } \\
\text { duct }\end{array}$ \\
\hline endostyle & & & $\begin{array}{l}\text { endostyle } \\
\text { disc }\end{array}$ & $\begin{array}{l}\text { endostyle } \\
\text { disc }\end{array}$ & elongate post & terior to anterior & endostyle & & & & endostyle & $\begin{array}{l}\text { endostyle with } \\
\text { endostylar } \\
\text { appendix }\end{array}$ \\
\hline $\begin{array}{l}\text { peripharyngeal } \\
\text { band }\end{array}$ & $\begin{array}{l}\text { pericoronal groove, } \\
\text { peripheral phalynx }\end{array}$ & & & & & can observe & & & & & & \\
\hline \multicolumn{13}{|l|}{$\begin{array}{l}\text { retropharyngeal } \\
\text { band }\end{array}$} \\
\hline stalk and villi & $\begin{array}{l}\text { preoral lobe, stolon, } \\
\text { substratum, } \\
\text { foldfast, base }\end{array}$ & & preoral lobe & $\begin{array}{l}\text { elongate } \\
\text { preoral } \\
\text { lobe }\end{array}$ & stalk & & & & & & stalk and villi & $\begin{array}{l}\text { short stalk and } \\
\text { many villi }\end{array}$ \\
\hline atrial cavity & $\begin{array}{l}\text { peribranchial sac, } \\
\text { cloacal cavity }\end{array}$ & & & & & can observe & & & & & & \\
\hline
\end{tabular}



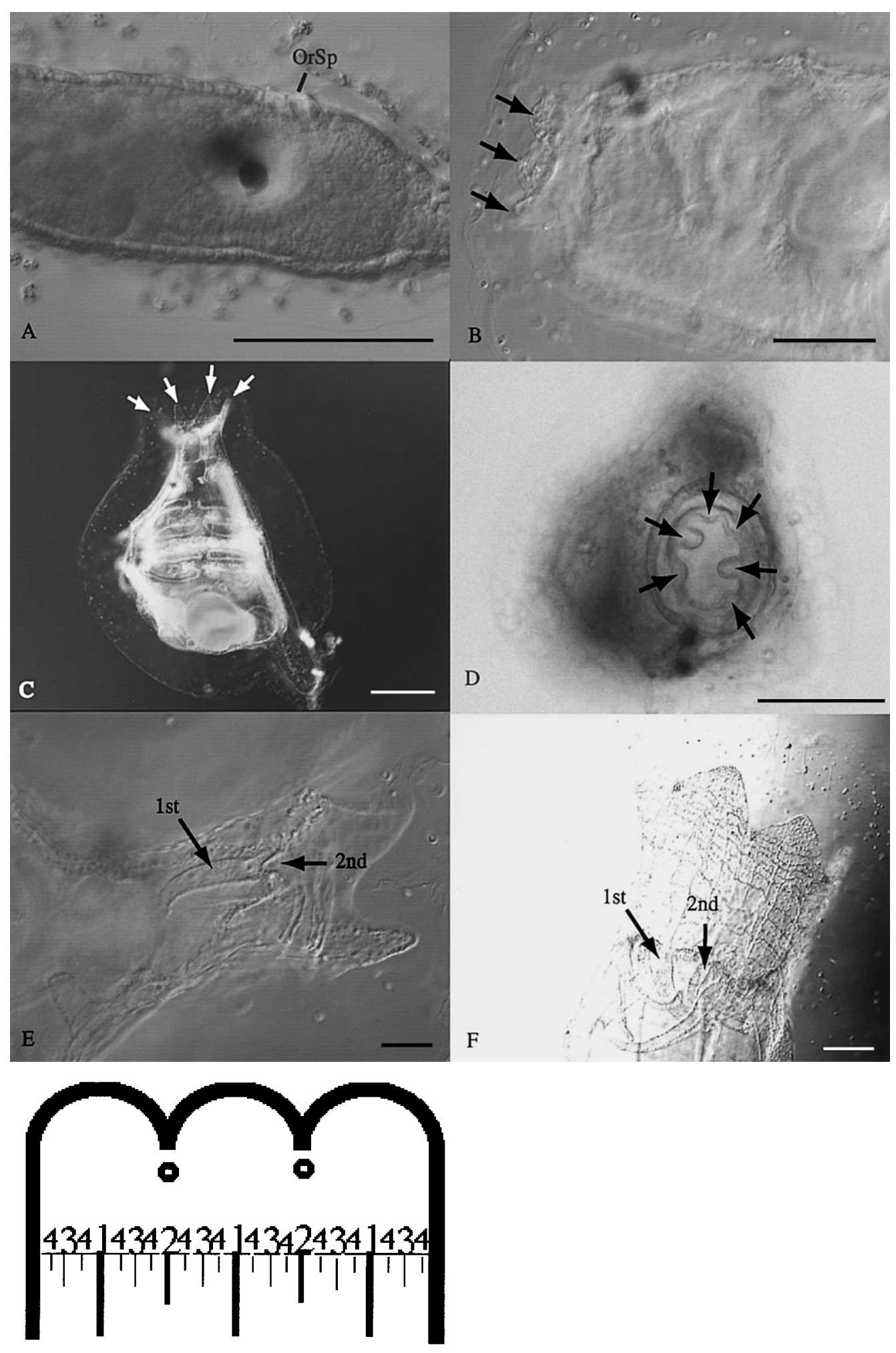

G

Fig. 2. The development of the oral siphon. (A) Trunk region of a larva, 4-7 hr after hatching. OrSp, oral siphon placode. (B) Late rotation stage (48 hr). Three oral lobes can be seen on the left side of the juvenile (arrows). (C) The $V$ protostigmata stage (day-7 8). Four oral lobes can be observed on the right side of the juvenile (white arrows). (D) Anterior view of the late rotation stage ( $48 \mathrm{hr}$ ). Six tentacles can be observed (arrows). (E) The oral siphon at the V protostigmata stage (day-7 8; 1st, 1st tentacle; 2nd, 2nd tentacle). (F) The oral siphon at the 2nd ascidian stage (day-12 14; 1st, 1st tentacle; 2nd, 2nd tentacle). Scale bars, $100 \mu \mathrm{m}$. (G) Diagram of the size and arrangement of the tentacles. The numbers represent the orders to which the tentacles belong. Half circles indicate the oral lobes. Small circles indicate the oral pigments. 
after hatching (during rotation of the body axis), the oral siphon opens but does not contract in response to stimuli (Fig. 6A, B). At day-3 after hatching, the oral siphon begins to contract in response to stimuli, and ascidians become able to eat food (Fig. 6C). There are 6-8 oral lobes in the oral siphon at this stage (Fig. 2B). At day-8 after hatching, most ascidians have 8 oral lobes (Fig. 2C).

\section{Tentacle}

A ring of tentacles marks the base of the oral siphon. The tentacles are of different lengths and their position is also different relative to the oral lobes. The longest ones, which are positioned at the base of the oral lobes, are named the 1 st tentacles. The 2 nd tentacles are positioned between the 1st tentacles, while the 3rd tentacles are positioned between 1st and 2nd tentacles. The 4th tentacles are positioned among the 1st, 2nd and 3rd tentacles (Millar, 1953; Fig. 2G). The tentacle was called the "branchial tentacle" by Hinman and Degnan (2000) and "oral tentacle" by Satoh (1994).

Tentacles are first observed at the end of rotation of the body axis. There are only six 1st tentacles (Fig. 2D). The fact that the tentacles are related to the oral lobes may explain why the number of first oral lobes is six. The 2nd tentacles are observed at day-8 (Fig. 2E), and the 3rd tentacles are not clearly observed by the 2 nd ascidian stage (14 days after hatching, Fig. 2F).

\section{Oral pigments and atrial pigments}

Millar (1953) and Goodbody (1974) discussed in detail the nature of these tissues in relation to light sensitivity. Millar (1953) reported that ascidians direct their body towards light when they are illuminated from one direction and that they turn the oral siphon towards the light when they can not direct their body as a whole, although this phenomenon does not unequivocally support the idea that the oral pigments and/or atrial pigments are light-sensitive organs. Goodbody (1974) stated the opinion that no experimental results so far obtained provide direct evidence that the pigments are a part of the light-sensitive organ. This question remains to be answered. Pigments are situated on the outer surface, in the notches between the oral and atrial lobe. There are characteristically eight oral pigments and six atrial pigments. Sometimes we find adults that have seven or nine pigments in nature. Oral pigments and atrial pigments were also called ocelli.

The oral pigments are first observed at day-5 after hatching, but without red-color. The number of oral pigments is closely related to the number of the oral lobes. At day-8 after hatching, the oral pigments are red-colored. The 2nd ascidian stage juveniles normally have eight oral pigments. The atrial pigments are first observed at the 2nd ascidian stage, sometimes including a few pigmented ones (Fig. 1E).

\section{Atrial siphon}

The atrial siphon has six atrial lobes with six pigments.
The transverse muscle is well developed around the atrial siphon. The atrial siphon was called the "atrial pore" by Willey (1893a) and "peribranchial siphon" by Berrill (1947). The atrial siphon is observed 4-9 hr after hatching of larvae as two "atrial siphon placodes (or atrial pores)" on both sides of the larva (Fig. 3A). Then 24-48 hr after hatching (during rotation of the body axis), the pre-atrial siphon opens, but it does not contract in response to a stimulus. At day-3 after hatching, the pre-atrial siphon becomes able to contract in response to a stimulus, and the ascidian become able to excrete its excrement. Then the two pre-atrial siphons move slowly toward the dorsal side (Fig. 3B-D), and they begin to fuse with each other at day-10 12 after hatching. The fusion is completed by the 2 nd ascidian stage, when the pre-atrial siphons have become the atrial siphon, which has six atrial lobes above it (Figs. 1E and 6G).

\section{Nervous system}

The adult ganglion is a white spindle-shaped body that is forked at the anterior and posterior ends, from which paired nerves originate. The adult neural gland is an ovoid body of spongy texture lying immediately ventral to the ganglion (Millar, 1953). Willey (1893b) sometimes called the ganglion and neural gland the brain and hypophysis, respectively. The dorsal tubercle is often called the ciliated funnel. This tissue lies anterior to the neural gland with a horse-shoe shape (Millar, 1953; Fig. 4D). The visceral nerve and the dorsal strand are closely connected with one another. The visceral nerve originates from the ganglion between the roots of the two posterior nerves. It almost immediately passes into the roof of the branchial sac where it is embedded in the connective tissue above the dorsal vessel (Millar, 1953). The dorsal strand originates from the posterior end of the duct of the neural gland. It runs along the roof of the pharynx and, after passing between the oesophagus and rectum (Millar, 1953). The roof of the branchial sac that run visceral nerve and the dorsal strand is called dorsal fold by Mackie et al. (1974). Development of the ganglion and neural gland was described well by Willey (1893b); according to his description, development of the ganglion and neural gland begins at the larval stage. Then, about the time of budding off of the two intermediate stigmata from the two primary stigmata, the ganglion attains a much greater development than in the preceding stage (Willey, 1893b). In recent years, changes in the nervous systems during metamorphosis in Ciona intestinalis were observed using the monoclonal antibody UA301 by Takamura (2002). According to Takamura (2002), a posterior sensory vesicle remained and became an adult cerebral ganglion. On the other hand, an anterior part of the sensory vesicle, the so called "neurohypophisis", became a dorsal tubercle (ciliated funnel) of the neural gland rather than part of the cerebral ganglion. When the juvenile rotates its body axis, the larval brain vessel is broken rapidly (Fig. 4A). Then, from the end of this rotation until the I, IV protostigmata stage, the ganglion can be observed clearly as being at stage III 

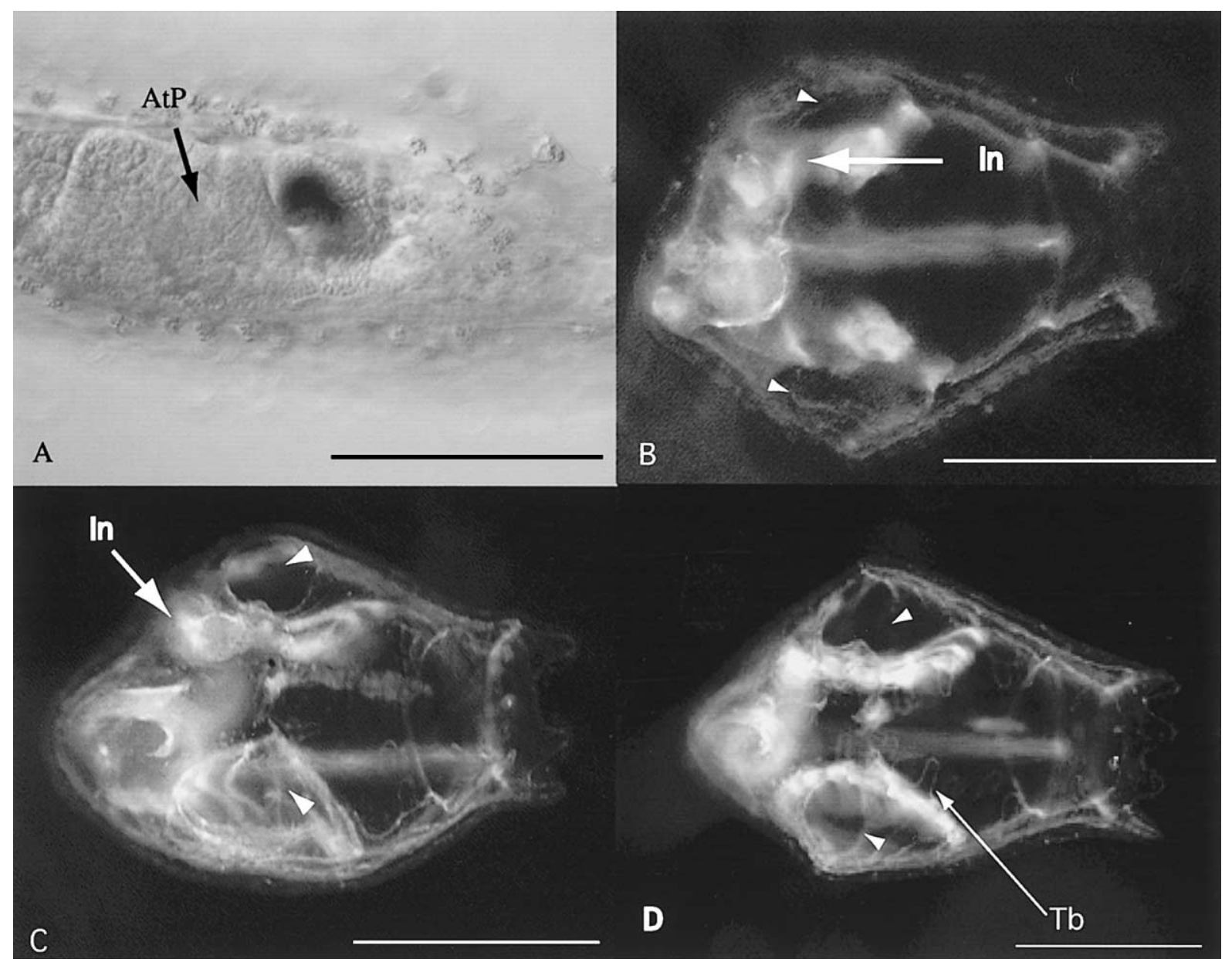

Fig. 3. The development of the atrial siphon. (A) Trunk region of a larva, 4-7 hr after hatching. AtP, atrial siphon placode. (B-D) Dorsal views of 1 st ascidian stages. In, intestine; Tb, tongue bud. Arrowheads indicate the position of opening of the pre-atrial siphon. (B) I, IV protostigmata stage (day-3). (C) II, III protostigmata stage (day-5). (D) V protostigmata stage (day-7 8). Scale bars, $100 \mu \mathrm{m}$.

(Willey, 1893b; Fig. 4B, C). At day-8 after hatching, we can easy distinguish the neural gland from the ganglion (Fig. 4D). They grow larger at later stages. However, the white color can not be seen yet at the 2nd ascidian stage (Fig. $1 \mathrm{~F})$. As shown in Fig. 4D, only one embryonic pigmented cell (maybe corresponding to the ocellus) is observed at this stage. The embryonic otolith and ocellus were extruded into blood vessel during the 1st ascidian stage (e.g., Fig. 6F near the $\mathrm{V}$ protostigmata). Furthermore, there is some red pigment in the ganglion (Fig. 1F). This red pigment can be observed transiently at from the $\mathrm{V}$ protostigmata stage until the 2 nd ascidian stage (Fig. 1F; data not shown at $\mathrm{V}$ protostigmata stage), but cannot be observed in adult ascidians. A horse-shaped dorsal tubercle was first observed at day- 5 after hatching with the ciliary activity (Fig. 6D). The dorsal fold (dorsal strand) is found $48 \mathrm{hr}$ after hatching (Fig. 4B).

\section{Longitudinal muscle}

The longitudinal muscle bands have been named (from ventral toward dorsal) L1, L2, L3a, L3b, L4 and L5 (Millar, 1953). The oral siphon is supplied by muscles $L 1$ to $L 3 b$ and the atrial siphon is supplied by the muscles L4 and L5 (Millar, 1953). Berrill (1947) described about longitudinal muscle bands by saying "While the number of protostigmata increases, the number of longitudinal muscle strands also increases from one to six or seven, the strands thereafter only increasing in individual thickness and not in number". We therefore named the longitudinal muscles $L 1$ to $L 5$, corresponding to Millar's designations, during adult development (Fig. 1A).

The longitudinal muscle is first observed at the stage of rotation of the body axis and it branches to L1 and L2 at a late stage of the rotation (Fig. $5 \mathrm{~A}$ ). About day- 5 to day- 8 after hatching, L3a, L3b and L4 are observed (Fig. 5B, C). L5 is observed at day-12 after hatching (Fig. 5D), but L3b sometimes elongates toward the atrial siphon.

\section{Stigmata (protostigmata)}

The stigmata are long and narrow with their major axis along the pharynx. A number of stigmata are enclosed in each mesh formed by the intersection of longitudinal and interstigmatic transverse bars (Millar, 1953). In the early stage of stigmata development, the axis of the protostigmata 


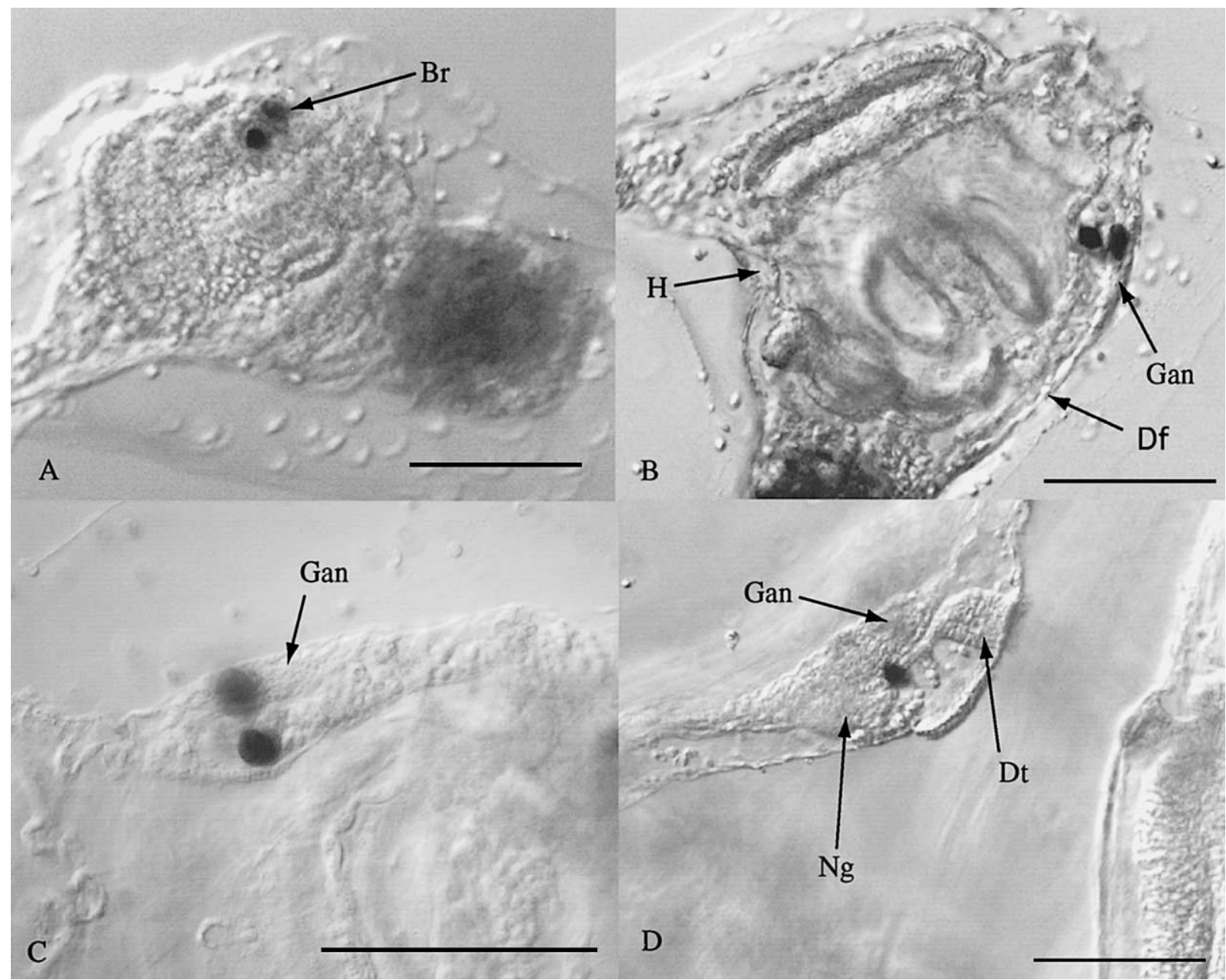

Fig. 4. The development of the adult nervous system. (A) The beginning of the late rotation stage (24 hr after hatching). (B) The end of the late rotation stage (48 hr). (C) High magnification of the ganglion at the I, IV protostigmata stage (day-3). (D) High magnification of the ganglion at the V protostigmata stage (day-8). Br, brain vessel; $\mathrm{H}$, heart; Df, dorsal fold; Gan, ganglion; $\mathrm{Ng}$, neural gland; and Dt, dorsal tubercle. Scale bars, $100 \mu \mathrm{m}$.

is dorso-ventral. Then, the direction of the antero-posterior axes of the stigmata change, a phenomenon that was first noticed by Krohn (Willey, 1893a). Stigmata are sometimes called gills or gill slits and called protostigmata in the early stage. The developmental and division patterns of stigmata until the 2nd ascidian stage were described well by Willey (1893a) and Berrill (1947). Our observations yielded almost the same results. The protostigmata first becomes detectable $12 \mathrm{hr}$ after hatching (the beginning of the late stage of the rotation of the body axis) as single I and single IV protostigmata (Fig. 6A). Second, at day-5 6 after hatching, small, single II and III protostigmata are observed on the ventral side of the pharynx (Fig. 6D). Third, at day-7 8 afer hatching, a single $\mathrm{V}$ protostigmatum is observed. At this time, I and IV protostigmata are divided into two or more protostigmata and II and III protostigmata elongate towards the dorsal side and often are divided in two protostigmata (Fig. 6E). Fourth, at day-10 12 after hatching, a single VI protostigmatum is observed. At this moment, the numbers of other types of protostigmata are I (4), II (3-4), III (2-4), IV
(2-4) and V (2), respectively (Fig. 6F). Fifth, at the 2nd ascidian stage, the direction of the axes of some stigmata changes to antero-posterior. At this time, the numbers of other protostigmata are I (8-12), II (8-12), III (8-12), IV (812), $\mathrm{V}(4-6)$ and $\mathrm{VI}(2-4)$, respectively (Figs. $1 \mathrm{~A}$ and $6 \mathrm{G}$ ). Temporary starvation readily inhibits the protostigmata development or division, and it seems to be hard for the inhibited protostigmata to recover their developmental or divisional ability, even if foods are served again provided (data not shown).

\section{Transverse bar and languet}

Interstigmatic transverse bars run between the rows of stigmata, and between these bars are the parastigmatic transverse bars, which pass across the centers of the rows of stigmata. In many ascidian species, the roof of the phar$y n x$ has a dorsal lamina projecting ventrally into the cavity of the branchial sac, but in Ciona intestinalis this is replaced by a row of languets. Each languet corresponds in position to one of the transverse bars (Millar, 1953; Fig. 1B). The 


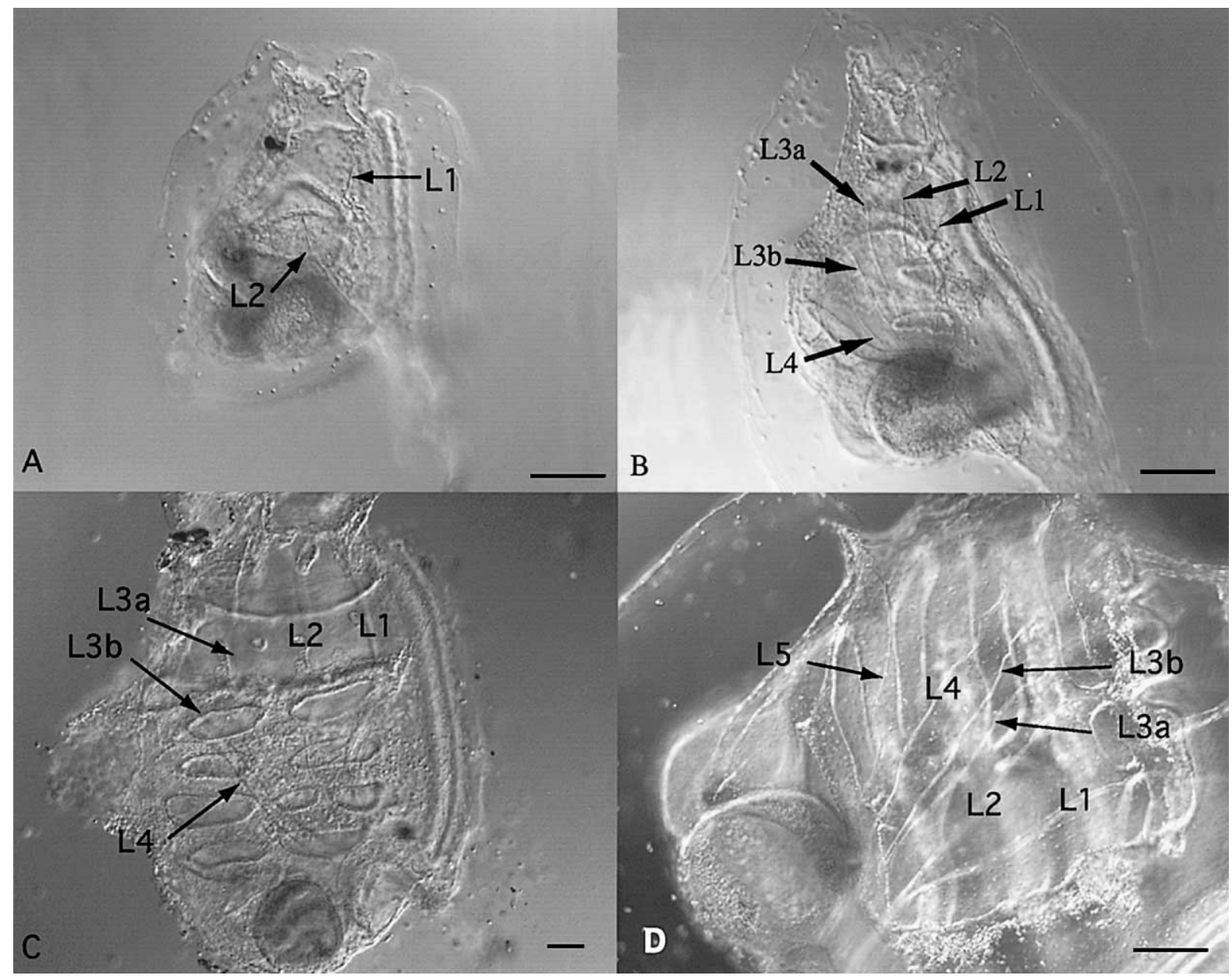

Fig. 5. The development of the longitudinal muscle. (A) I, IV protostigmata stage (day-3). (B) II, III protostigmata stage (day-5). (C) V protostigmata stage (day-7 8). (D) VI protostigmata stage (day-10 12). Scale bars, $100 \mu \mathrm{m}$.

transverse bar was called the "gill bar" by Mackie et al. (1974).

The transverse bar is observed at the stage just after new protostigmata are observed (Fig. 6D-G). For example, at the time when the $\mathrm{V}$ protostigmatum is first observed, the new transverse bars are observed between the I and II protostigmata and between the III and IV protostigmata (Fig. $6 \mathrm{E})$. The transverse bar that is situated between the II and III protostigmata was already observed at a previous stage (Fig. 6D), and no transverse bar is observed between IV and $\mathrm{V}$ stigmata (Fig. 6E). Soon after the new row of protostigmata develops, the dorsal part of pharynx gives rise to the new languet.

\section{Longitudinal bar and papilla}

Longitudinal bars, which are internal to the interstigmatic transverse bars, run along the whole length of the branchial sac, and are supported by the transverse bars. A papilla projects into the branchial cavity from the intersections of transverse and longitudinal bars (Millar, 1953). Between the anterior and posterior sides of protostigmata (not the dorsal and ventral sides), a tongue bud is observed
(Fig. 7A). This tongue bud was also called a "papilla" by Willey $(1893 \mathrm{a})$. The tongue buds elongate themselves in the anterior and posterior directions. Then the anterior and posterior sides of the bud become fused, forming the longitudinal bar. When the longitudinal bar is observed, the papilla is well developed on the top of the bud (Fig. 7A). We first observed the longitudinal bar at day-8 after hatching (Fig. $7 A)$.

\section{Heart}

The Ciona intestinalis heart mainly consists of the pericardium, cardiac raphe, myocardium, pericardiac body and heart lumen (Millar, 1953; Pope and Rowley, 2002). In the Ciona adult, the heart is V-shaped. The development of the heart was described by Willey (1893a) and Selys-Longchamps (1901) from the larval to juvenile stages and by Damas (1899) at late stages. Takamura (2002) traced the staining for UA301 antibody from the larva to the juvenile. He showed that the ventro-central part in the larval trunk stained with this antibody was the heart primordium. At the late stage of the rotation of the body axis, we first observe the heart beating. At this stage the heart is situated between 


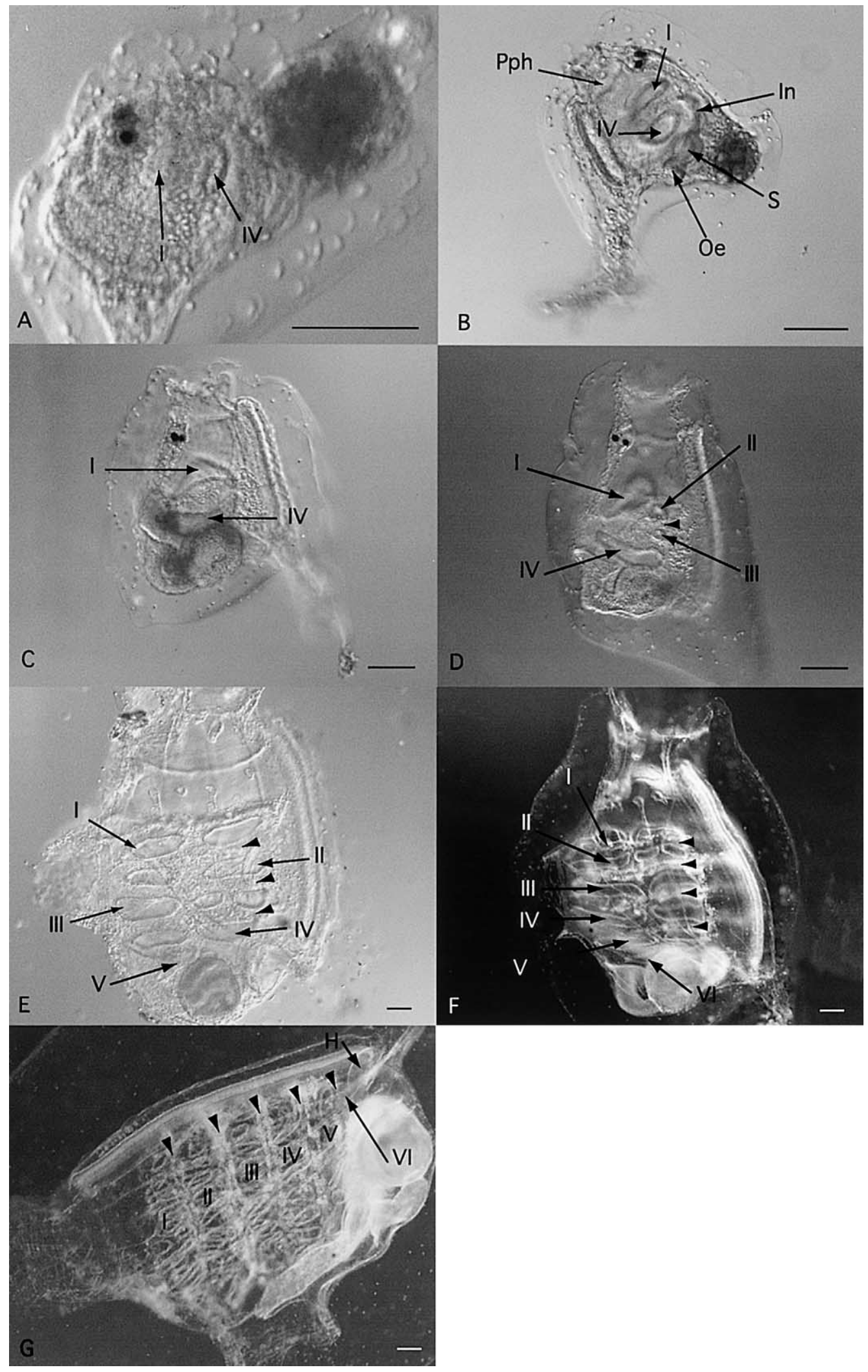

Fig. 6. The development of the protostigmata. (A) The beginning of the late rotation stage ( $24 \mathrm{hr}$ after hatching). (B) The end of the late rotation stage (48 hr). (C) I, IV protostigmata stage (day-3). (D) II, III protostigmata stage (day-5). (E) V protostigmata stage (day-7 8). (F) VI protostigmata stage (day-10 12). (G) 2nd ascidian stage (day-12 14). I, I protostigmata; II, II protostigmata; III, III protostigmata; IV, IV protostigmata; V, V protostigmata; VI, VI protostigmata; Pph, peripharyngeal band; Oe, oesophagus; S, stomach; In, intestine; and H, heart. Arrowheads indicate the transverse bar. Scale bars, $100 \mu \mathrm{m}$. 


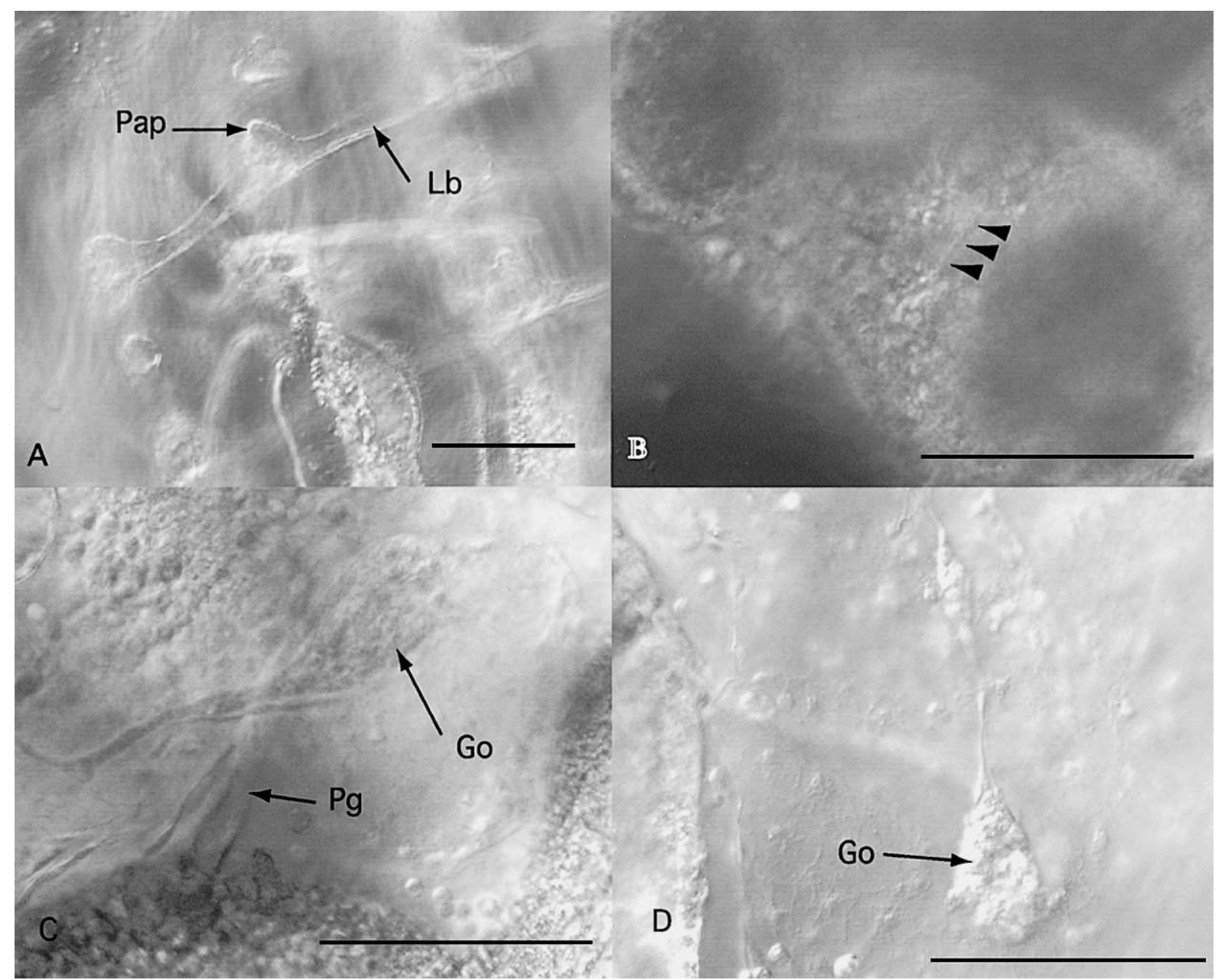

Fig. 7. The tissues and organs of the juvenile. (A) Longitudinal bar (Lb) and papilla (Pap) at $\vee$ protostigmata stage (day-8). (B) Pyloric gland (arrowheads) at I, IV protostigmata stage (day-3). (C) Gonad (Go) at V protostigmata stage (day-7 8). The gonad is positioned at near the pyloric gland (Pg). (D) Gonad (Go) at VI protostigmata stage (day-10 12). Scale bars, $100 \mu \mathrm{m}$.

the posterior end of the endostyle and the stomach (Fig. 4B). Until the 2nd ascidian stage, the heart is round-shaped, and the pericardiac body is not found in the pericardium (Fig. 6G). In our observations, the heart becomes V-shaped about 20 days after hatching but the pericardiac body is not found in the pericardium at this stage (data not shown). The blood cells are first observed at the late stage of body axis rotation as blood begins flowing.

\section{Digestive organ}

The digestive system of Ciona intestinalis is composed of a pharynx, oesophagus, stomach, intestine, and pyloric gland. Yonge (1925) distinguished the mid-gut and hind-gut based on the cell types which composed the intestine of Ciona intestinalis. The development of the pyloric gland was described based on two different sets of observations. Willey (1893a) described the pyloric gland development during the rotation stage, whereas Berrill (1947) stated that the pyloric gland is not discernible in dissected adult. Yamamoto and Okada (1999) observed its presence in 4-day juveniles, which have I and IV protostigmata in each side of the pharynx.

The intestine is first observed as an intestine disc in the posterior region of the larval trunk 4-9 hr after hatching (Fig. $8 \mathrm{C})$. The intestine disc probably contains the oesophagus and stomach but we could not distinguish them from each other. We could distinguish the oesophagus and stomach from the intestine at the later stage of body axis rotation (Fig. 6B). At day-3 after hatching, the cilia of the protostigmata begin to move, the oral and pre-atrial siphon contract with the muscle, and the juvenile can eat food. The oesophagus is clearly connected with the pharynx on the dorsal side of body, and an anus clearly opens to the left pre-atrial siphon. The pyloric gland which is a very small and narrow structure, is observed at day-3 after hatching (Fig. 7B). With careful observation, the pyloric gland can be seen in juveniles at about the same time as noted in Yamamoto and Okada's report (1999). The pyloric gland is undetectable earlier than day-3 after hatching. The pyloric gland gradually thickens, and branches off around the 2nd ascidian stage (Figs. 1D and 7C). 


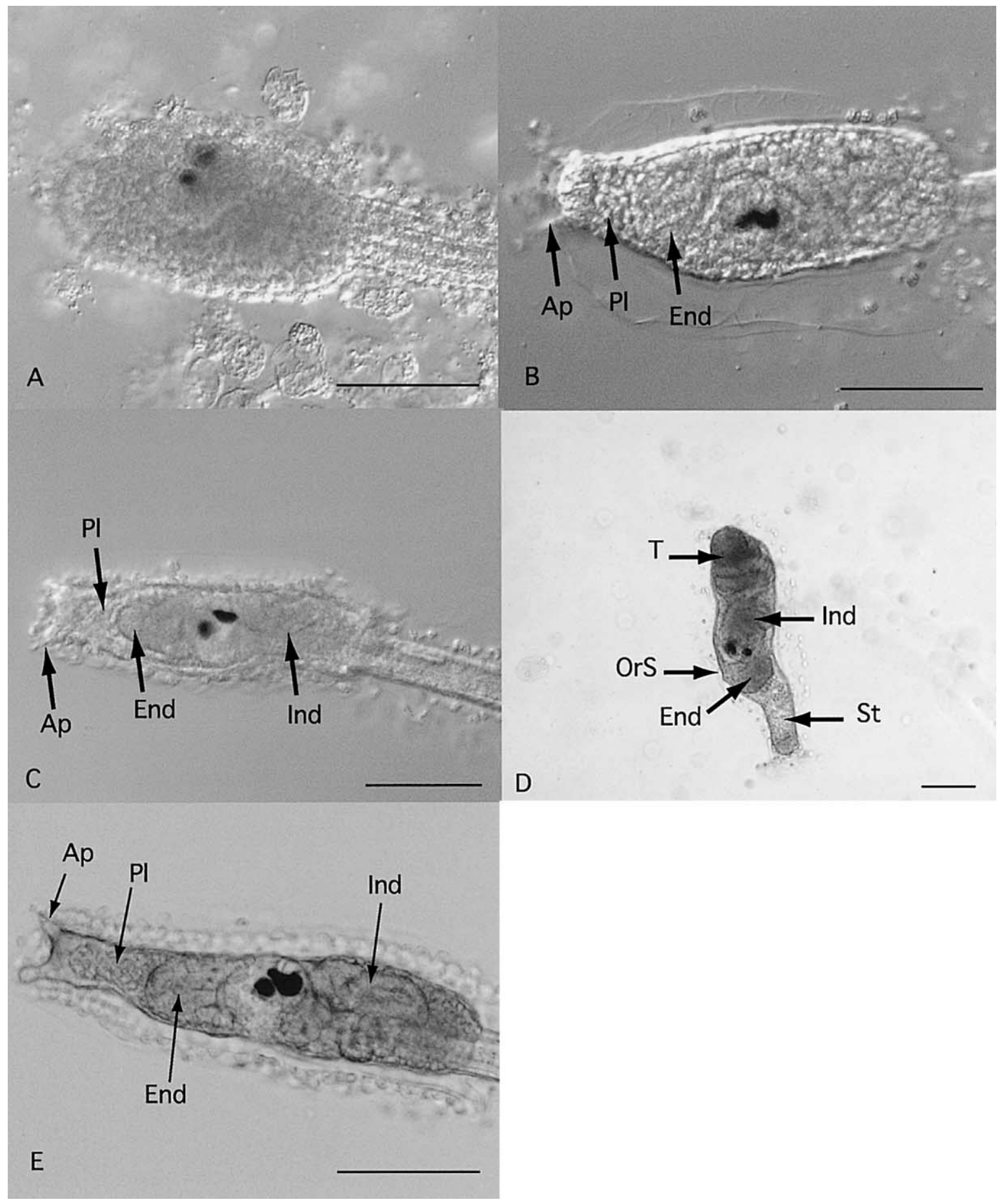

Fig. 8. Early developmental stages of Ciona intestinalis juveniles and larva with missed tail resorption. (A) The early-swimming larva stage (0-2 hr after hatching). (B) The mid-swimming larva stage (2-4 hr after hatching). (C) The late-swimming larva stage (4-9 hr after hatching). (D) Early rotation stage (12-24 hr after hatching). (E) Larva with missed tail resorption. This figure shows a larva that was bred during for 3 days after hatching at $20^{\circ} \mathrm{C}$. Ap, adhesive papillae; PI, preoral lobe; End, endostyle disc; Ind, intestine disc; T, tail residue; OrS, oral siphon; and St, stalk. Scale bars, $100 \mu \mathrm{m}$.

\section{Gonad}

The gonad of the Ciona intestinalis juvenile is situated between the intestine and stomach, near the pyloric gland (Yamamoto and Okada, 1999; Okada and Yamamoto,
1999). According to the observations of those authors, the gonad was first observed in day-2 juveniles by electron microscopy and was first observed in day-3 juveniles by light microscopy. In 9- to 10-day juveniles the cavity is enlarged 
and the gonad rudiment becomes an oval vesicle (Yamamoto and Okada, 1999). Takamura et al. (2002) traced the staining for Ciona vasa homologue $(\mathrm{CiVH})$ antibody from middle tailbud stage to young adulthood. They showed that positive cells are present in the endodermal strand in the middle-tailbud stage embryos and larvae. Moreover, they observed the gonad development at light-microscopic level and showed that these positive cells moved into gonad primordium during metamorphosis and differentiated into eggs and sperms in adulthood. Although the timing we observed, and their standard timing have about a day's deviation, the results are almost the same when the results of Yamamoto and Okada's observation are compared with our results by referring to the number of protostigmata (e.g., Fig. 7C, D).

\section{Endostyle}

The endostyle is situated at the ventral-most portion of the Ciona body. The anterior hood is located at the anterior end of the endostyle and is connected to the peripharyngeal band. The posterior end of endostyle is connected to the retropharyngeal band, and only in Ciona intestinalis, the posterior end of the endostyle has an endostylar appendix. This structure is not seen in Ciona savignyi (Millar, 1953; Hoshino and Nishikawa, 1985).

At the swimming larval stage, the endostyle disc is situated in the anterior trunk region. We were first able to observe it at 2-4 $\mathrm{hr}$ after hatching, but it was not so clear then (Fig. 8B), while at 4-9 hr after hatching, it became much clearer (Fig. 8C). During rotation of the body axis, the endostyle elongates along the anterior-posterior axis of the adult (Fig. 8D and Fig. 6A, B). It seems that the endostylar appendix has not been observed at the 2 nd ascidian stage yet (Fig. 1A). The peripharyngeal band (pericoronal groove or peripheral phalanx) is first observed at the late stage of body axis rotation (Fig. 6B), but we have not yet been able to detect how the retropharyngeal band forms during the development of Ciona juveniles.

\section{Stalk and villi}

Both stalk and villi are tissues that are used for settlement of the ascidian. The stalk comes from the preoral lobe that is situated on the anterior most end of the larva (Willey, 1893a). The villi are branched from the stalk or epidermis and are usually thinner than the stalk (Millar, 1953). The stalks and villi are also called the stolon, preoral lobe, base or foldfast. We call this structure preoral lobe in the larva and call stalk after tail resorption.

The preoral lobe begins to elongate $2-4 \mathrm{hr}$ after hatching (Fig. 8B), and then after settlement the preoral lobe rapidly elongates as the stalk (Fig. 8D). During the development of adults, the stalk gradually becomes shorter and the number of villi increases.

\section{Larvae with missed tail resorption}

When larvae are kept at $5-7^{\circ} \mathrm{C}$, many the larvae fail to undergo tail resorption (Hirai, 1963). Even if they are shifted to $20^{\circ} \mathrm{C}$ thereafter, the larva does not undergo the tail resorption. The larvae with missed tail resorption have highly elongate preoral lobes, a clearer endostyle disc and a clearer intestine disc in their trunk region than larvae at later stages (Fig. 8E). The larvae bred much longer (e.g., 8 days or more) at $4^{\circ} \mathrm{C}$ have a beating heart in their trunk region (data not shown). In such missed-tail-resorption larvae, the endostyle disc does not elongate to the anteriorposterior side, no stomach is observed, stigmata do not open and the brain is not generally broken. Thus, the development of Ciona intestinalis adult tissues occurs at larval stage, but the larvae must at least undergo the tail resorption in order to further develop adult tissues, except for early heart development and heart beating.

\section{The difference between the 2 nd ascidian stage and adult stage}

There are at least two differences between the 2nd ascidian stage and the adult tissue according to the description of Millar (1953) (Table 1). First, the gonad is not matured at the 2 nd ascidian stage. Second, red pigment at tip of the sperm duct is not seen in the beginning of the 2nd ascidian stage. Furthermore, there are some tissues in the 2nd ascidian stage of Ciona intestinalis whose functions are the same as those of the adult but there are not the same in appearance or number. For example, the heart at the 2nd ascidian stage does not look V-shaped, we can not observe a pericardiac body (Fig. 6G), and the ganglion has red pigment in it transiently. Although there are some differences in tissues and organs between the adult and 2nd ascidian stages, almost all adult tissues and organs are present at the 2 nd ascidian stage.

\section{New staging of Ciona intestinalis larvae and juveniles}

We observed Ciona intestinalis adult development until the 2nd ascidian stage, and monitored the formation of many tissues and organs. These results are summarized in Table 1. Many tissues were formed by the end of rotation of the body axis. However, many tissues such as the neural gland or protostigmata changed in form at least until they reached to the 2 nd ascidian stage. The gonad and longitudinal bar were formed during the period of our observations. Therefore, many events must occur during the stages before and during juvenile development.

We accordingly propose a new detailed staging system. Ciona adult development has already started at the swimming larva stage. In our observation, three stages are distinguishable in Ciona swimming larvae. The first stage is of just hatched larvae, which have a rounded trunk and do not have a well-developed adhesive papilla (Fig. 8A). The second stage starts at about 2-4 hr after hatching. These larvae have three adhesive papillae and a preoral lobe in the elongated trunk (Fig. 8B). Then, the last stage starts at about 4-9 hr after hatching. These larvae have an endostyle disc and an intestine disc as adult tissues in the trunk region (Fig. 8C). Then, the Ciona larvae attach to the substratum 
to begin tail resorption and the rotation of their body axis. In this third stage period, at least two sub-stages may be distinguished. The first sub-stage lasts from the beginning of tail resorption until a phase of rotation in which the digestive organs are not complete and the heart does not beat (Fig. 8D). The second sub-stage lasts until the end of rotation, which distinguishes the oesophagus and stomach from the intestine (Fig. 4B). We should distinguish the first ascidian stage according to the way that protostigmata are made because the development of the protostigmata is the most definitive step at this stage in our observation. The first ascidian stage can be classified into four stages of development according to the characteristics of the protostigmata. That is, the I, IV protostigmata stage that has I and IV protostigmata, the II, III protostigmata stage that has II and III in addition to the former stage, $\mathrm{V}$ protostigmata stage and $\mathrm{VI}$ protostigmata stage in that order.

We propose this new staging for Ciona intestinalis, and describe the most characteristic forms below.

\section{SWIMMING LARVA}

\section{Swimming larva}

Stage 0 (early-swimming larva; 0-2 hr after hatching: $20^{\circ} \mathrm{C}$ ): This stage is of just hatched larvae. At this stage, the larvae have a rounded trunk and have not developed the adhesive papillae (Fig. 8A).

Stage 1 (mid-swimming larva; 2-4 hr): The larvae at this stage have three adhesive papillae in their trunk, and a preoral lobe can be distinguished. They can attach to the substratum but can not begin the tail resorption.

Stage 2 (late-swimming larva; 4-9 hr): At this stage, the larvae elongate the preoral lobe. The endostyle disc and intestine disc are detectable in the trunk region of the larvae. They begin to invaginate the oral and atrial placodes.

\section{JUVENILE}

\section{Rotation of the body axis}

Stage 3a (early rotation; 12-24 hr): At this sub-stage, Ciona intestinalis begins tail resorption and then rotates its body axis. The larval brain begins to break, and the endostyle begins to elongate from the posterior toward the anterior.

Stage 3b (late rotation; 24-48 hr): At this stage the oesophagus and stomach are distinguishable from the intestine disc. The heart begins to beating. The ganglion has reached the stage III that was mentioned by Willey (1893b).

\section{1st ascidian stage}

Stage 4 (I, IV protostigmata stage; day-3): The direction of the endostyle is completely parallel to the stolon. The I and IV protostigmata are opened. The juveniles can eat food and can contract their siphons.

Stage 5 (II, III protostigmata stage; day-5): The II and III protostigmata are seen, and we can observe a transverse bar between II and III. The longitudinal muscle can be observed as L3a, 3b and L4.

Stage 6 (V protostigmata stage; day-7 8): The V protostigmata can be observed and the new transverse bars are situated between I and II, and between III and VI. The cavity of the gonad is enlarged. Some second tentacles can be observed. The tongue buds are joined together to form longitudinal bars.

Stage 7 (VI protostigmata stage; day-10 12): The VI protostigmata can be observed and one more new transverse bar is observed between VI and V. Longitudinal bar L5 can be observed near the pre-atrial siphon. The two preatrial siphons begin to fuse.

\section{2nd ascidian stage}

Stage 8 (2nd ascidian stage; day-12 14): The pre-atrial siphons completely fuse to form the atrial siphon. The axis of the protostigmata gradually changes from dorsal-ventral to anterior-posterior. The new transverse bar is found between $\mathrm{V}$ and $\mathrm{VI}$.

\section{ADULT}

\section{Adult (adult; 2.5-3 months)}

The ascidians contain eggs and sperm, and red-pigment on the tip of the sperm duct. The heart changes from round-shaped to V-shaped. The adults have lost the red pigment in the ganglion. The endostylar appendix can be observed (Ciona intestinalis only).

\section{ACKNOWLEDGMENTS}

This work was supported by the Grant for the Biodiversity Research of the 21st Century COE (A14) and by a Grant-in-Aid for Scientific Research from JSPS to NS (No.12358012). We are grateful to Maizuru Fisheries Research Station of Kyoto University for facilitating parts of this work there.

\section{REFERENCES}

Barrington EJW (1964) Hormones and Evolution. English Univ Press, London

Berrill NJ (1947) Development of Ciona. J Mar Biol Assoc 26: 616625

Damas D (1899) Les formations épicardiques chez Ciona intestinalis. Arch Biol T 16: 1-25

Dehal P, Satou Y, Campbell RK et al. (2002) The draft genome of Ciona intestinalis: insights into chordate and vertebrate origins. Science 298: 2157-2167

Goodbody I (1974) The physiology of ascidians. Adv Mar Biol 12: 1149

Hinman VF, Degnan BM (2000) Retinoic acid perturbs Otx gene expression in the ascidian pharynx. Dev Genes Evol 210: 129139

Hirai E (1963) On the separation of the metamorphosis of the body and of the tail of ascidian larva. Bull Mar Boil Stat Asamushi 11: $127-131$

Hirano T, Nishida H (1997) Developmental fates of larval tissues 
after metamorphosis in ascidian Halocynthia roretzi. I. Origin of mesodermal tissues of the juvenile. Dev Biol 192: 199-210

Hirano T, Nishida H (2000) Developmental fates of larval tissues after metamorphosis in the ascidian, Halocynthia roretzi. II. Origin of endodermal tissues of the juvenile. Dev Genes Evol 210: $55-63$

Hoshino Z, Nishikawa T (1985) Taxonomic studies of Ciona intestinalis (L.) and its allies. Publ Seto Mar Biol Lab 30: 61-79

Kowalevsky A (1866) Entwicklungsgeschichte der einfachen Ascidien. Mem l'Acad St Petersbourg Ser 7: 1-19

Kowalevsky A (1871) Weitere studien über die Entwicklung der einfachen Ascidien. Arch Mikr Anat 7: 101-130

Mackie GO, Paul DH, Singla CM, Sleigh MA, Williams DE (1974) Branchial innervation and ciliary control in the ascidian Corella. Proc R Soc Lond B 187: 1-35

Millar RH (1953) Ciona. L M B C Mem typ Br mar PI Anim 35: 1-123

Ogasawara M, Di Lauro R, Satoh N (1999) Ascidian homologs of mammalian thyroid peroxidase genes are expressed in the thyroid-equivalent region of the endostyle. J Exp Zool (Mol Dev Evol) 285: 158-169

Ogasawara M, Sasaki A, Metoki H, Shin-i T, Kohara Y, Satoh N, Satou Y (2002) Gene expression profiles in young adult Ciona intestinalis. Dev Genes Evol 212: 173-185

Okada T, Yamamoto M (1999) Differentiation of the gonad rudiment into ovary and testis in the solitary ascidian, Ciona intestinalis. Dev Growth Differ 41: 759-768

Pope EC, Rowley AF (2002) The heart of Ciona intestinalis: eicosanoid-generating capacity and the effects of precursor fatty acids and eicosanoids on heart rate. J Exp Biol 205: 15771583

Roule L (1884) Recherches sur les Ascidies Simples des côtes de Provence. Phallusiadées 1e partie. Monographie de la Ciona intestinalis. Ann Mus Hist Nat Marseille 2: 1-270

Sasakura Y, Awazu S, Chiba S, Satoh N (2003) Germ-line transgenesis of the Tc1/mariner superfamily transposon Minos in Ciona intestinalis. Proc Natl Acad Sci USA 100: 7726-7730

Sato Y, Morisawa M (1999) Loss of test cells leads to the formation of new tunic surface cells and abnormal metamorphosis in larvae of Ciona intestinalis (Chordata, ascidiacea). Dev Genes Evol 209: 592-600
Sato Y, Terakado K, Morisawa M (1997) Test cell migration and tunic formation during post-hatching development of the larva of the ascidian, Ciona intestinalis. Dev Growth Differ 39: 117126

Satoh N (1994) Developmental Biology of Ascidians. Cambridge Univ Press, Cambridge

Satoh N, Satou Y, Davidson B, Levine M (2003) Ciona intestinalis: an emerging model for whole-genome analyses. Trends Genet 19: $376-381$

Selys-Longchamps M (1901) Développement du coeur, du péricarde et des épicardes chez Ciona intestinalis. Arch Biol T 17: 499-542

Simmen MW, Leitgeb S, Clark VH, Jones SJ, Bird A (1998) Gene number in an invertebrate chordate, Ciona intestinalis. Proc Natl Acad Sci USA 95: 4437-4440

Takamura K (2002) Changes in the nervous systems from larva to juvenile in Ciona intestinalis. Rep Res Inst Mar Biores Fukuyama Univ 12: 27-35

Takamura K, Fujimura M, Yamaguchi Y (2002) Primordial germ cells originate from the endodermal strand cells in the ascidian Ciona intestinalis. Dev Genes Evol 212: 11-18

Willey A (1893a) Studies on the Protochordata. I. On the origin of the branchial stigmata, praeoral lobe, endostyle, atrial cavities, etc. in Ciona intestinalis, Linn., with remarks on Clavelina lepadiformis. Q J Micr Sci 34: 317-360

Willey A (1893b) Studies on the Protochordata. II. The development of the neuro-hypophyseal system in Ciona intestinalis and Clavelina lepadiformis, with an account of the origin of the sense organs in Ascidia mentula. Q J Micr Sci 35: 295-316

Yamamoto M, Okada T (1999) Origin of the gonad in the juvenile of a solitary ascidian, Ciona intestinalis. Dev Growth Differ 41: 7379

Yonge CM (1925) Studies on the comparative phisiology of digestion. III. Secretion, digestion, and assimilation in the gut of Ciona intestinalis. British J Exp Biol 2: 373-388

(Received October 24, 2003 / Accepted December 8, 2003) 